\title{
A propósito de Péndulo del Retorno de Carlos Pacheco, poeta
}

\author{
Wilbert Arguedas Pizarro* \\ Y es así porque la poesía existe mucho \\ antes de que el mapa politico dividiera \\ los corazones centroamericanos. \\ El autor
}

Recibido: setiembre 2010 • Aceptado: noviembre 2010

\section{RESUMEN}

Se concibe en este artículo a la poesía como manifestación viva, actuante. Su poesía es tránsito donde confluyen hombres y mujeres, que conforman el mundo poético en el texto Péndulo del retorno, de Carlos Pacheco. El texto de este poeta intenta releer el mundo poético. Es una poesía comprometida, no solo poesía por la poesía, sino con un mensaje fundamental en torno al vital existir de los seres humanos.

Palabras clave: posmodernidad, yo lírico, imágenes, heterogéneo, socialismo.

\begin{abstract}
In this article I conceive poetry as a living, acting manisfetation. His poetry is a transit where men and women meet, those who make up the poetic world in the text Return of the Pendulum, by Carlos Pacheco. The text by the poet tries to re-read the poetic world. It is a committed poetry, not only poetry for poetry, but with a fundamental message about the vital existence of human beings.
\end{abstract}

Key words: postmodernity, I lyrical images, heterogeneous, socialism.

* $\quad$ Bachiller en Lingüística y Literatura, Universidad Nacional de Costa Rica, UNA. Licenciado en la Enseñanza del Español, Universidad de las Ciencias y el Arte. Profesor del Conservatorio Castella. Tutor de Literatura e Identidad Costarricense, Universidad Estatal a Distancia, UNED. 
Con el libro de poesía Péndulo del Retorno, de Carlos Pacheco, estamos ante la sensación inequívoca de que la poesía tiene el mismo sentido que ha tenido desde sus orígenes remotos. Me refiero a que no es una cuestión de modus operandi poético. Sea que no es un asunto de discusión a ultranza de ismos o de tintes regionalistas. Es poesía en sí misma. Viva. Ciertamente es poesía de la posmodernidad y es socialista. Pero, ¿qué poesía no lo es o no lo será?... En este sentido, con Carlos Pacheco estamos ante un religare o reunión poética.

Esta reunión o religión del quehacer poético es lo que confirma un aspecto del sentido del que hablo, viene en dos vertientes: se reúnen los intertextos bíblicos:

Sabe que el ángel desata la ira y el amor en los matorrales, Misterio; o, la primera estrofa del poema Dos caminos, incluso cuando se abren puertas en el cielo, Gozo, y los no bíblicos, como la inocencia brutal del Minotauro, Laberinto, o el verso: El hilo de Ariadna y textos complementarios, Misterio, o, entre lo sagrado y lo profano, como cuando yo, con rostro de ángel o demonio, entré a Masaya, Sombras, por decirlo de alguna forma, pero con una fina irreverencia o algo socarrona, despistada, sin mala intención, pueblerina. Una chinfonía.

La remotidad antes aludida, Pacheco se la trae al hombro desde la Odisea (incluyendo a su hiperbólico: con los cien ojos de Argos, Corazón de olvido) y el eco de inevitable Caribdis, Recuento, y la clava en la cristiandad de Los hijos de Yavé (que) insisten en el río renovado, Patios y arrugas, sin que una $\mathrm{u}$ otra se ofusquen, es decir las reúne con un vaso de agua, Misterio, convocando a los espíritus de uno y otro lado: como ojivas de ese Dios imperturbable, Medusa.

Pero a la Odisea le hace una gambeta: la imaginó como sirena que escucha el canto del poeta, El poeta. Verso clave es este por referencial, que magistralmente nos señala el arts poética del yo lírico. Referencia que se alarga a lo humano, a lo social convocado con el otro: Carlos y yo no hemos quedado con el dolor del poeta, El poeta. O esta otra gambeta, (que desliga lo poético de lo no poético, por decirlo de alguna forma incómoda aunque vaga o inexacta si se me permite, porque todo lo que está en un libro de poesía es y será poesía): $Y$ hablamos de Carlos, "sin poemas y sin literatura”, Doña Herminia.

Ahora bien, esta secuencia dizque sagrada dizque profana no es gratis. Es sufrida. Oscila. Péndula. Devela la realidad del yo lírico. La misma que ha sido develada in illo tempore. Al decir devela la realidad del yo lírico lo que se está diciendo es que la múltiple realidad humana está siendo comunicada de manera 
estética. Sea esta realidad sagrada, profana, mágica u onírica: alguien sueña el mismo sueño, Sueño; irrumpen los fantasmas en el alba, María, con luz o sin ella: cuando el Sol fue espejo de agua, Masaya, o cuando alli el reflejo del Sol es un pez, Yo me pregunto, y el estallido del molotov que alumbra la noche en el callejón, Doña Herminia. También cuando profetiza que El brillo de luz será mañana túnel inclaudicable, Sueño.

Por supuesto que los claroscuros y fugacidades materiales-inmateriales son eslabones de la diaria y dura vida del yo lírico. Vida enlazada a mujeres (a Damaris, a Judith, doña Herminia, Medusa, María, Calipso, La otra y ahí siguen más...) y a muertes entre natural y de rifle, como la de los héroes del BLI, Sombras, o cuando tercia el fusil la ternura, Umbral, a familiares y lugares por donde la poesía y el poeta fueron haciéndose.

Es pues un poemario que traduce obsesiones, imágenes, dictados de la mente, la pasión, comunicación con el otro o los otros, sean estos nicaragüenses o costarricenses, que para la poesía esa frontera no existe. Y es así porque la poesía existe mucho antes de que el mapa político dividiera los corazones centroamericanos. Es una convocatoria entre nosotros a través del lenguaje en la que el yo lírico se encuentra y se traduce así mismo.
El concepto de lo onírico no es vago en este poemario ni es aspiración de algo o hacia algo solo por experiencia esperanzadora; es más una forma de pensamiento, una especie de filosofía sin ser filosofía, de vigilancia entre lo real y lo estético o de lo estético. Al decir estética estoy diciendo que en el trasfondo hay una visión de lo humano esencial o de lo que nos hace humanos. Aquí hago un paréntesis para advertir quizás la base temática del poemario: la existencia humana con sus múltiples dimensiones. La existencia se manifiesta entonces cuando: El enigma nos envuelve cuando descubrimos que todo está en movimiento, somos una idea, un acto, presencia fugaz y ausencia, Sueño. O También: y el testimonio de patios y arrugas indica que la condición humana es un tránsito continuo hacia todos los rincones de la realidad, Patios y arrugas.

$\mathrm{Si}$ observamos con cuidado, se podría decir que la temática del poemario no viene del realismo evidente o del exteriorismo (impresionista) con que se ha calificado cierto sector de la poesía nicaragüense. No quiere decir que, del todo, no haya nada de exteriorismo en Péndulo del Retorno, sino que este subyace en segundo plano, como remanencia. El libro está lleno de esos ejemplos.

Hay que tener cuidado y no decir que es otro libro estereotipado 
que se decanta por la misma cultura de Solentiname: $Y$ Solentiname fue fruta de pan antes de que los poetas elevaran sus voces, Fin de Siglo. Mejor dicho, el poeta se impulsa desde esta estética exteriorista o la toma de pretexto para explorar otras vías de la existencia humana. Insisto en que el exteriorismo no es lo que da al poemario vida, no porque más bien en este poema ese exteriorismo es un recuerdo, una imagen de lo antiguo, de Fin de Siglo... Por lo tanto tampoco, es una renuncia ni un intento absurdo de revivir lo ya dicho por los Clásicos nicaragüenses. Es un intertexto, no una contradicción. El poeta llama a observar lo antiguo con ojos nuevos: Extendi la mirada desde el barco; pretendi remover la nostalgia que habita sobre las aguas, Fin de siglo.

Aceptamos el antiguo concepto de literariedad con que el Formalismo Ruso vio la autonomía al lenguaje poético. Esto sirve para decir que en el libro de Carlos Pacheco hay una concentración y ruptura de espacios e inventa temporalidades autónomas. No tanto por lo que diga el Formalismo sino por la esencia misma del arte literario. Es un asumir sobre la realidad no literaria. Esto quiere decir que, aunque, se citen acontecimientos cotidianos, urbanos, civiles, militares, nostalgias, sueños, amores... el poemario, de manera dinámica, produce su propia historicidad en su literariedad o inmanencia. Esto es: Péndulo del Retorno no es un poemario de carácter historicista ni sociológico. No al estilo de la literatura histórica ni testimonial. Aunque se determinen realidades cotidianas con escepticismo de siglo, Principio de siglo; o se haya ido a París, la algarabía de Toro Venado, béisbol, los 30 de setiembre, la Octava..., Umbral. Se insiste que el poemario crea su propia realidad y tiempo. Un tiempo ido sin derroche de lágrimas, un tiempo futuro pero sin esperanza exagerada. Únicamente instancia espaciotemporal necesaria para ambientar el poemario sin que se tome por cierta la referencialidad implícita; ni tiene porque ser referencial. Eso no le corresponde a ningún tipo de arte. Queda claro el fundamento del Formalismo.

$\mathrm{Si}$ alguien insiste en que el poemario tiene ese carácter exteriorista o realista es porque está pensando en el descubrimiento de una nación olvidada. Una identidad sociocultural. En un volver la mirada hacia aquella otra república nicaragüense que un día se levantó revolucionaria inspirada por Sandino. Es decir, la búsqueda del ser o del ideal nicaragüense. De lo auténtico nica como utopía. De lo artesanal, lo visual, lo anecdótico, lo rural... Como aquella postura de la Generación de poetas españoles de 1898: el reencuentro con lo español: 
lenguaje, vida de los pueblos, espiritualidad, paisajes...

No se le está negando el paisajismo evidente al poemario, sino que este existe en virtud de la imagen visual propia del pintor o esteta que también es el poeta. De hecho la pintura exteriorista de Solentiname existe en las palabras, la artesanía, la pintura, las tradiciones de un pueblo.

Con lo que estoy de acuerdo es que Carlos Pacheco nos da un aviso de que no se puede desprender de su cultura; ningún ser humano de por sí lo puede hacer. Entonces para no asumir represiones es perfectible su asumir esa cultura y retratarla con las palabras con que mejor pueda o conozca y, ese es su lenguaje, hecho imagen sencilla, directa, de pueblo, a veces. Pero, insisto, ese es andamiaje. Es formalismo, es lo que se ve. Por dentro, lo que no vemos, está la intrincada red de símbolos, códigos, reflejos, abstracciones, carencias, contradicciones..., aspectos propios de la existencia humana.

Péndulo del Retorno si cambia algo la poesía. El libro se crea a partir de la poesía que habla el lenguaje del pueblo o que es "comprometida social y políticamente", pero esta base no es lo principal en ella.

Lo principal es la existencia humana en toda su dimensión por encima de cualquier exteriorismo o impresionismo. Es la dignificación del ser humano aunque creemos que la vida es eterna y que somos inefables (donde) quedamos hoscos, vacios, en esta maratón de idas $y$ vueltas..., Sueño. En este sentido, igual de reveladores son los poemas Inmigrantes I e Inmigrante II.

Estoy de acuerdo que Nicaragua no sería la misma sin la poesía conversacional. Lo mismo cabría decir de Francia sin la poesía de la resistencia o de Alemania sin la poesía del Romanticismo en el descubrir su identidad nacional en el tránsito de la vida a la muerte. O en Cuba, a la que su poesía ha ayudado a soportar el aislamiento y, así, el exteriorismo, el Romanticismo, el premodernismo de los poetas del 98 español, el antiguo costumbrismo costarricense, fueron o han sido ayuda, por ejemplo, para encontrar una identidad, una ciudadanía, una personalidad colectiva, con una dignidad de saberse perteneciente a un país, con sus defectos o virtudes, pero suyo. Cuando eso ocurre, es cuando se dice que el poeta socialmente ha ayudado, que su poesía sí cambia en algo al pueblo o la cultura donde está instaurada.

El poeta nos llama a cuentas. Nos dice qué cosas hemos dejado pasar por alto. Qué superficiales somos. Es aquí que retomo la idea de lo estético no como un asunto de arte sino de reflexión sobre la vida a través del código estético. 
Es renovar pensamientos y valores sociales y humanos por encima de etiquetas. Es validar lo heterogéneo. Es tocar todas las cuerdas de la guitarra. La realidad, el mito, el sueño, el amor, la muerte, la vida, la revolución, la contradicción, la imaginación popular...

\section{Que no se queden otras cosas sin advertir}

Primero, difiero del retrato de la portada. Me parece que si bien la imagen erótica de la mujer es una constante psíquica y una experiencia imaginativa como un clarineo (que) pasa por el prisma seductor de su piel trashumada, Medusa. Lo mismo que los poemas Calipso, Gaviota, Animales en celo y otros; no representa la égida central del poemario. Es una parte más de la existencia humana, no la esencia de ella. Para cierto sector social lo erótico es una representación de las relaciones liberales o sin represiones, es natural y humano. También lo erótico debe tener una ética y una estética. Pero no es lo único porque entonces la portada puede confabularse con el contenido existencial total del texto poético. No es un negar del espacio erótico; es verlo como un todo en la conformación de las diversas visiones de mundo, culturas, nacionalidades y personalidades. Es cuestión ideológica, posmoderna y estética, en suma.
De esto último, se toma en cuenta la visión posmoderna que amarra las cuerdas de la lírica de Péndulo del Retorno. Sobra decir que el título así lo evidencia. Es la imagen de una nueva sensibilidad, ideas, estados de ánimo que se relacionan también con nuevas realidades sociales que vienen a establecerse sobre realidades con sus discursos agotados, en este caso, insisto, en que el exteriorismo de este poemario es una base, no una totalidad ni una cosmovisión. Por tal motivo, aunque afirmo cierta ruptura no estoy diciendo que exista exclusión total. Ya expliqué que no hay ser humano abstraído de su cultura. Pienso en una continuidad pero con otros argumentos. No en una batalla contra el exteriorismo. Es una realidad después de otra. Veo ahí el concepto de posmodernidad en el poemario. No se puede prescindir per se de lo moderno que lo precede porque la posmodernidad, de alguna forma, asume lo moderno.

El poeta fija las coordenadas históricas, sociales e ideológicas de la realidad y justifica con ellas su arts poética. Ya no son suficientes los términos de poesía de vanguardia para su propuesta estética. Es así porque el conjunto de valores, códigos y actitudes que subyacen en el poemario no pueden negarse a su existencia o a su permanencia ideológica, cultural, sensibilidad, 
espiritualidad del tiempo que le toca vivir, no del que ya vivió. Quiero decir, el poemario no fue publicado hace años, es reciente, aunque con dejo de nostalgia. Es actual.

El poemario no esconde su crítica social pero no asume una acidez que niega la existencia de lo que fue materialmente fundamento histórico de la modernidad: el desarrollo tecnológico (el progreso cruza el pueblo, Patios y arrugas), el costo humano y económico de la clase trabajadora y la manifiesta telaraña del poder burgués sobre todo ello. Ejemplo de ello es el poema En París. Pero, advierto en esta fotografía de París, el desarrollo y los límites de lo humano y lo social, es un vínculo ambivalente como en el poema Dialéctica.

A la larga, en el trasfondo de la temática de Péndulo del Retorno hay un proyecto de socialismo posmoderno que avisora una realidad todavía no liberada de concepciones productivistas, mundialistas o globalizantes (formas frescas de relaciones de explotación de hombres y pueblos) que cada día son más avasalladoras o enajenantes de los países submodernos (mal llamados tercermundistas), a lo que se le opone la poesía como proyecto dignificador de lo humano; condenando, con o sin encendidos aros (Darío) la función ideológica de llevar al ser humano a la inacción, la impotencia o la pasividad.
Porque en los tiempos sombríos se cantará también con la sabiduría que profesa la poesía, Álamo.

\section{Bibliografía}

Barzuna Pérez, Guillermo. (1983). Signos y arquetipos en la poética de Rubén Darío, en revista Letras enero-diciembre, $\mathrm{n}^{\circ}$ 11-12. Escuela de Literatura y Ciencias del Lenguaje, Universidad Nacional Autónoma, Heredia: EUNA.

Benjamin, Walter (1980). Poesía y capitalismo. Iluminaciones 2. Madrid: Taurus Ediciones S. A.

Brecht, Bertolt. (1984). El arte y la política. Managua: Editorial Nueva Nicaragua.

Carvajal Alvarado, Guillermo et al. (2007). Humanismo en tiempos de posmodernidad (historia/sociología/ciencias sociales). San José, Costa Rica: Librería Alma Mater.

Collazos, Óscar et al. (sfe). Literatura en la revolución y revolución en la literatura. México: Siglo XXI Editores.

Coronel Urtecho, José. (1985). Rápido tránsito (al ritmo de Norteamérica). Managua: Editorial Nueva Nicaragua.

Corrales, Adriano. (2004). Caza del poeta. San José: Ediciones Andrómeda.

Cuevas Molina, Rafael. (2008). Sandino y la intelectualidad costarricense (Nacionalismo antiimperialista en Nicaragua y Costa Rica, 1927-1934). San José: EUNED.

Eliot, Tomas Stern. (1959). Sobre la poesía $y$ los poetas. Buenos Aires: Sur S.R.L. 
Gaos, Vicente (Editor). (1976). Antología del grupo poético de 1927. Madrid: Ediciones Cátedra S.A.

Guillén, Jorge. (1972). Lenguaje y poesía. Madrid: Alianza Editorial.

Pacheco Solórzano, Carlos Adán. (2007). Péndulo del retorno. San José, Costa Rica: Ediciones Andrómeda.

Ministerio de Educación Pública. (1976). Poesía moderna española e hispanoamericana. (Selección y notas de Elena Nascimento y Joaquín Gutiérrez Mangel). San José: EUNA.

Monge, Carlos F. (2005). El vanguardismo literario en Costa Rica. Heredia: EUNA.

Salinas, Pedro. (1975). La poesía de Rubén Dario. Barcelona: Seix Barral S.A.
Saravia, Juan Ramón. (1985). Pasajes bíblicos (de ida y vuelta). Honduras: Editorial Guaymuras S.A.

Vianu, Tudor. (1971). Los problemas de la metáfora. Argentina: Editorial Universitaria de Buenos Aires (EUDEBA).

(1986). Poesía Nicaragüense (Selección y prólogo de Ernesto Cardenal). Managua: Editorial Nueva Nicaragua. (1986). Poesía Politica Nicaragüense (Selección y prólogo de Francisco de Asís Fernández). Managua: Ministerio de Cultura.

(1979). Poesía de Solentiname, en revista Letras julio-agosto-setiembre, $\mathrm{n}^{\circ} 2$. Escuela de Literatura y Ciencias del Lenguaje, Universidad Nacional Autónoma, Heredia: EUNA. 